\title{
Resistance parameters of Alluvial Gravels from Static and Dynamic Triaxial Tests.
}

\author{
[ J. O. Morandi, R. J. Uliarte, A. E. Núñez ]
}

Abstract- In this paper, we present the results of a program of static and cyclic triaxial tests, isotropically consolidated and drained or not drained, intending to characterize the mechanical parameters of some typical alluvial gravels of the San Juan River. We determined the pre-seismic mechanical properties of these gravels: the hyperbolic curve stress-strain; the variation of the shear resistance in function of the confining pressure; the variation of the Young modulus with the initial confininig pressure; Young modulus with load-unload; the volumetric variation and variation of the $B$ modulus with the confining pressure. In order to carry out this triaxial tests, the following effective pressure values were used in the cell: 1.0 , $2.5,5.0$ and $9.0 \mathrm{~kg} / \mathrm{cm} 2$, in the case of the drained and of 1.0 , $2.5,5.0$ and $8.0 \mathrm{~kg} / \mathrm{cm} 2$, for not drained. Samples were molded to different relative densities of interest. The cyclic triaxial tests allowed us to determinate the dynamic properties of the abovementioned gravels: the variation of the pore pressure depending on the number of load cycles applied $[u=f(N c)]$; the variation of the axial deformation as a function of the number of load cycles applied $[\varepsilon a=f(N c)]$; the determination of the relationships: $r u=f(r n) ; \varepsilon a=f(r n) y \sigma d c / 2 / \sigma 3 c^{\prime}=f(N c$; for wich it were executed series of triaxial tests to different cyclical effective pressures in the cell: $2.5 ; 5.0$ and $7.0 \mathrm{~kg} / \mathrm{cm} 2$, facing cyclical deviatoric stresses $(+/-\sigma d c)$ who caused the liquefaction of the samples or axial deformation to a total of $\mathbf{1 0}$ $\%$, between 5 to 150 load cycles, to different values of relative density of the samples.

Keywords - Alluvial Gravels * Static and Dynamic Properties * Cyclic Triaxial Tests.

\section{Introduction}

In this paper we present the results of a program of static and dynamic triaxial (cyclical) tests, intending to characterize mechanically some of the typical alluvial gravels of the San Juan River, in the province of San Juan, Argentina, whose soil profile is composed of sandy gravels accompanied by variable proportions of rocks.

\section{J. O. Morandi}

Universidad Nacional de San Juan

Materials and Soils Institute

Argentina

\section{R. J. Uliarte}

Universidad Nacional de San Juan Argentina

\section{A. E. Núñez}

Universidad Nacional de San Juan Argentina

The cyclic triaxial tests were automatized, with controls and register of loads, pore pressure and axial deformation, by the use of transducers and an electronic system of data acquisition. The results presented here correspond to the alluvial gravels of the river and fields located nearby whose characteristics are summarized in Table 1 and Fig $\mathrm{N}^{\circ} 1$.

TABLE I. CHARACTERISTICS OF THE ALLUVIAL GRAVELS OF THE SAN JUAN RIVER TESTED.

\begin{tabular}{|c|c|c|c|c|}
\hline Property & \multicolumn{4}{|c|}{ Properties of the samples tested } \\
\hline Identification & $\begin{array}{r}\text { GP-GM } \\
\text { Ullum }\end{array}$ & $\begin{array}{c}\text { GP } \\
\text { Zonda }\end{array}$ & $\begin{array}{l}\text { GW } \\
\text { Ullum }\end{array}$ & $\begin{array}{c}\text { Measuring } \\
\text { Cylinder Test }\end{array}$ \\
\hline$\gamma \mathrm{s}\left(\mathrm{Kg} / \mathrm{m}^{3}\right)$ & 2664 & 2666 & 2645 & \multirow{3}{*}{$\begin{array}{c}\phi=0.175 \mathrm{~m} \\
H=0.38 \mathrm{~m} \\
\operatorname{Dmax}=11 / 2 "\end{array}$} \\
\hline $\begin{array}{l}\gamma d \text { máx } \\
\left(\mathrm{Kg} / \mathrm{m}^{3}\right)\end{array}$ & 2357 & 2305 & 2344 & \\
\hline $\begin{array}{l}\gamma \mathrm{d} \text { mín } \\
\left(\mathrm{Kg} / \mathrm{m}^{3}\right)\end{array}$ & 1950 & 1814 & 1942 & \\
\hline
\end{tabular}

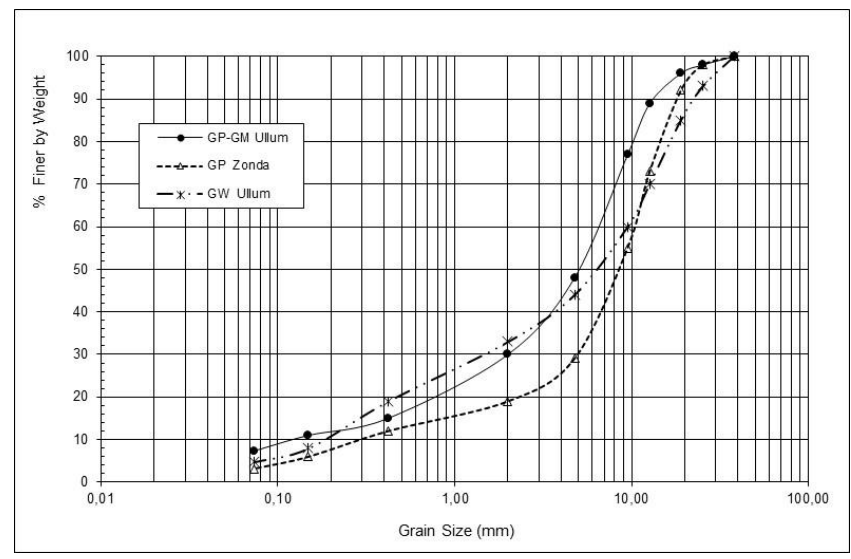

Figure 1. Grain size distribution curve

\section{Tests carried out}

\section{A. 2) Drained triaxial tests and not drained - Pre-Seismic Static Stability.}

The execution of a program of drained triaxial tests allowed us to determine the effective parameters of shear resistance of the soil: c' y $\phi$ '; the hyperbolic parameters: $\mathrm{a}=$ $1 / \mathrm{Ei}$ and $\mathrm{b}=1 / \sigma_{\mathrm{d} \text { max }}$; the relationship between the initial tangent modulus Ei and the confining pressure $\sigma_{3}$, which according to Janbu can be expressed as follows: $\mathrm{E}_{\mathrm{i}} / \mathrm{p}_{\mathrm{a}}=\mathrm{K}\left(\sigma_{3}\right.$ $\left(\mathrm{p}_{\mathrm{a}}\right)^{\mathrm{n}}$ and the volumetric deformation modulus of the soil, according to Janbu, can be expressed as: $\mathrm{B} / \mathrm{p}_{\mathrm{a}}=\mathrm{K}_{\mathrm{b}}\left(\sigma_{3} / \mathrm{p}_{\mathrm{a}}\right)^{\mathrm{m}}$, where $\mathrm{K}, \mathrm{n}, \mathrm{Kb}$ and $\mathrm{m}$ are experimental parameters to determine with the program of triaxial tests (Duncan et al 1980, Bolognesi 1987, 1988, Musante ET al 1987, Siddiqi et al 1987). With these data it is posible to model and obtain the pre-seismic stress state and strains in the dam, and verify a static failure of the same, in both conditions, drained as not drained. 
Proc. of the Third Intl. Conf. on Advances in Civil, Structural and Construction Engineering - CSCE 2015 Copyright (C) Institute of Research Engineers and Doctors, USA .All rights reserved.

ISBN: 978-1-63248-079-8 doi: 10.15224/ 978-1-63248-079-8-52

On a characteristic gravel (GP-GM, Ullum) of the sediment from the river located in Ullum (Fig. $\mathrm{N}^{\circ} 1$ ) were scheduled series of triaxial tests in condition static consolidated drained and not consolidated drained, to a relative density (RD) of $60 \%$ and $85 \%$, corresponding to the compactness of the alluvium of foundation and the granular material for dam shoulders respectively. At the RD of the alluvium of foundation ( $\mathrm{RD}=60 \%$ ) were made static triaxial tests with following effective pressures of cell:1.0 ; $2.5 ; 5.0$ and $9.0 \mathrm{~kg} / \mathrm{cm} 2$ in the case of the drained (Figs. $\mathrm{N}^{\circ}$ 2) and $1.0 ; 2.5 ; 5.0$ and $7.0 \mathrm{~kg} / \mathrm{cm} 2$ for not drained (Figs. No. 3).
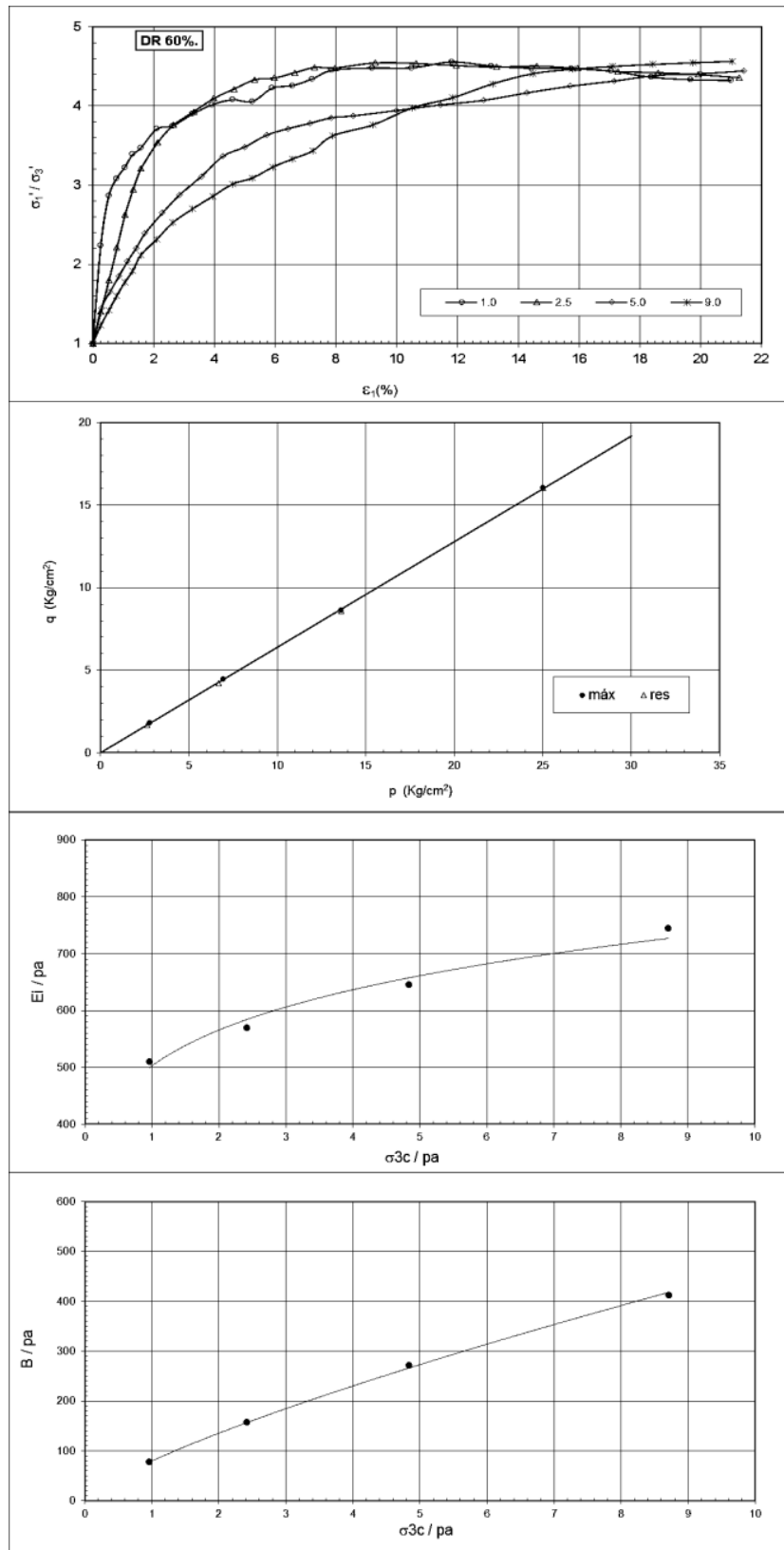

Figure 2. Triaxial drained. Foundation. GP-GM Ullum. DR60 \%.

The trials done at the relative density corresponding to the dam shoulders $(\mathrm{RD}=85 \%$ ) were carried out at pressures of cells of $1.0 ; 2.5 ; 5.0$ and $9.0 \mathrm{~kg} / \mathrm{cm} 2$, for the drained (Fig 4 ) and the not drained (Fig 5).
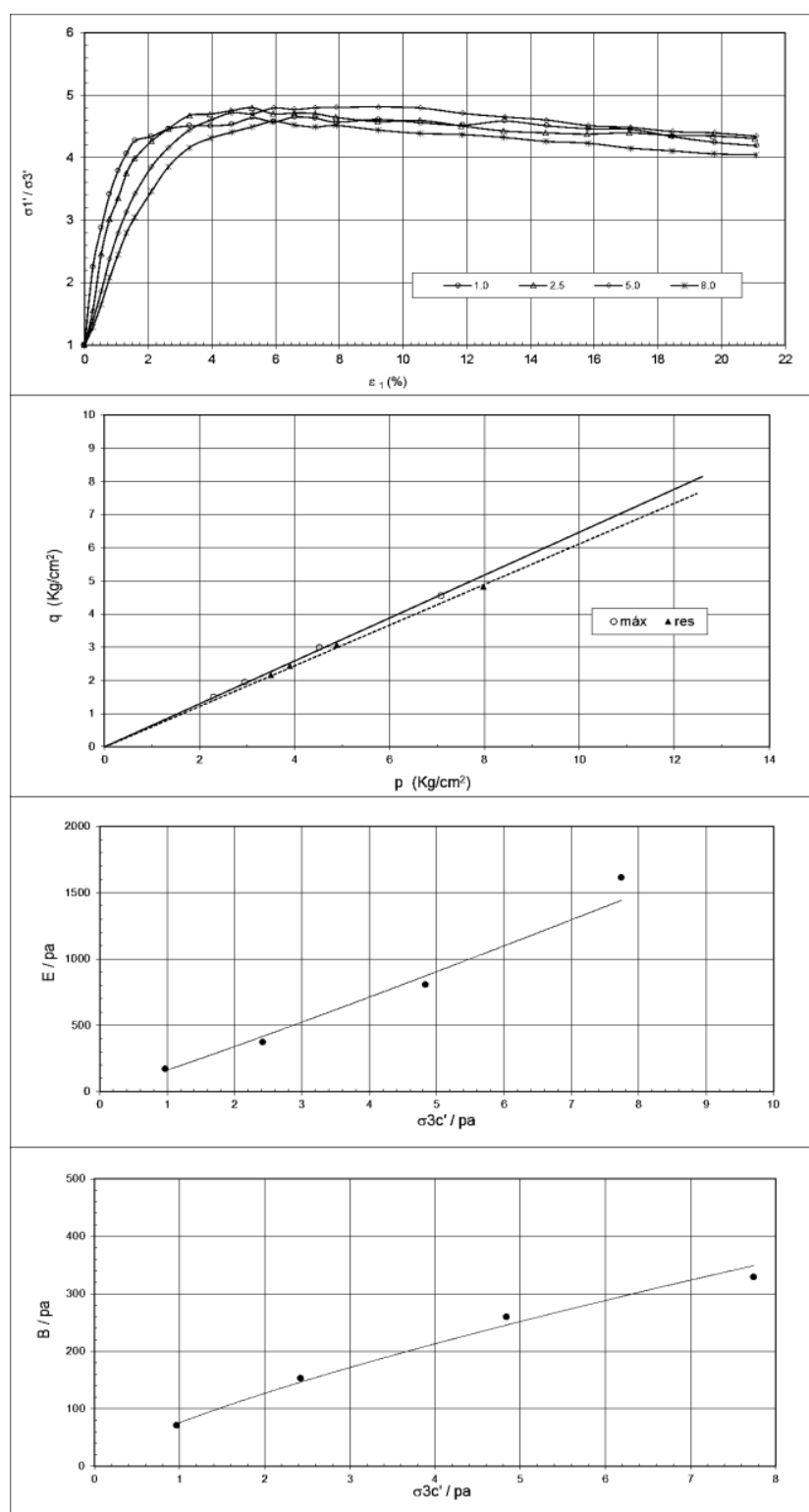

Figure 3. Not drained Triaxial. Foundation. GP-GM Ullum DR $60 \%$.

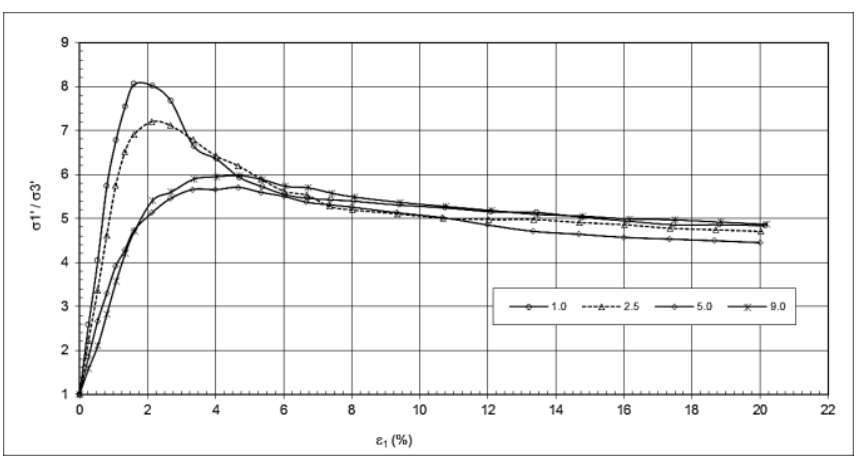

Figure 4. Triaxial drained. Espaldones. GP-GM Ullum DR $85 \%$. 
Proc. of the Third Intl. Conf. on Advances in Civil, Structural and Construction Engineering - CSCE 2015 Copyright $(\subseteq$ Institute of Research Engineers and Doctors, USA .All rights reserved.

ISBN: 978-1-63248-079-8 doi: 10.15224/ 978-1-63248-079-8-52
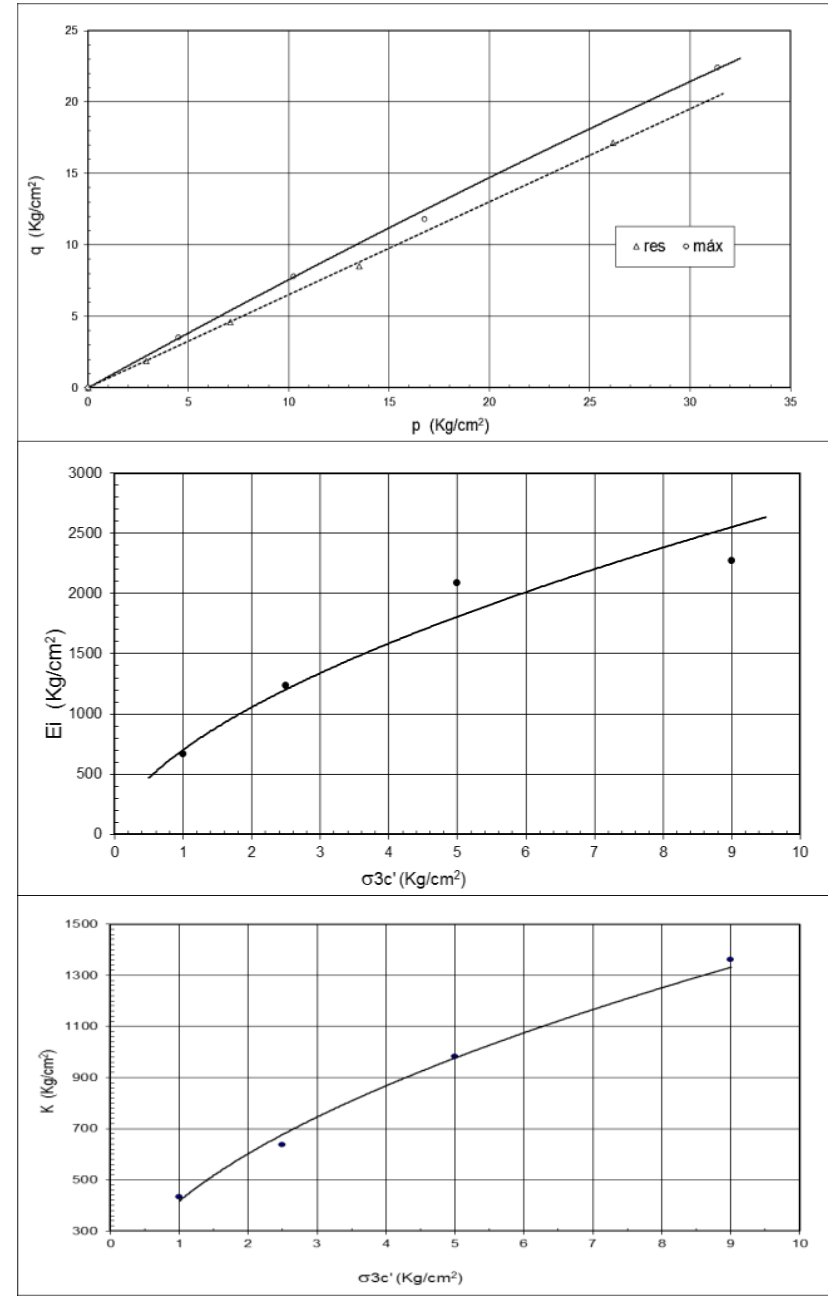

Figure 4. Cont.drained Triaxial. Dam Shoulders. GP-GM Ullum. DR85 $\%$.

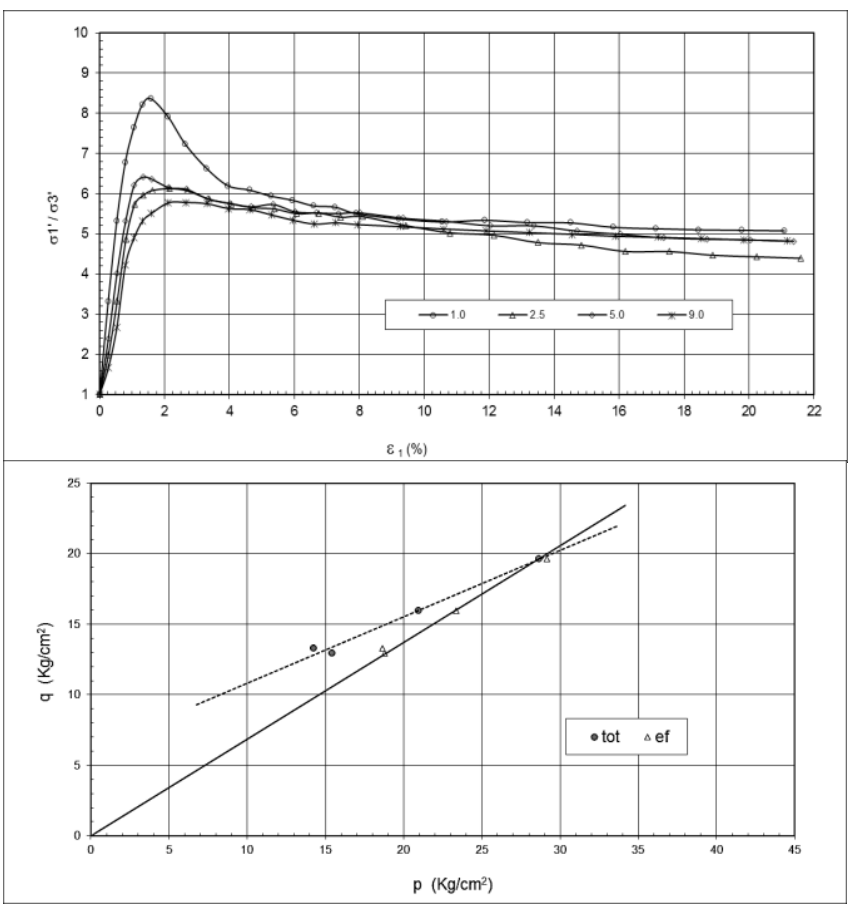

Figure 5. Not drained Triaxial. Dam Shoulders. GP-GM Ullum. DR85\%. 
Proc. of the Third Intl. Conf. on Advances in Civil, Structural and Construction Engineering - CSCE 2015 Copyright (C) Institute of Research Engineers and Doctors, USA .All rights reserved. ISBN: 978-1-63248-079-8 doi: 10.15224/ 978-1-63248-079-8-52

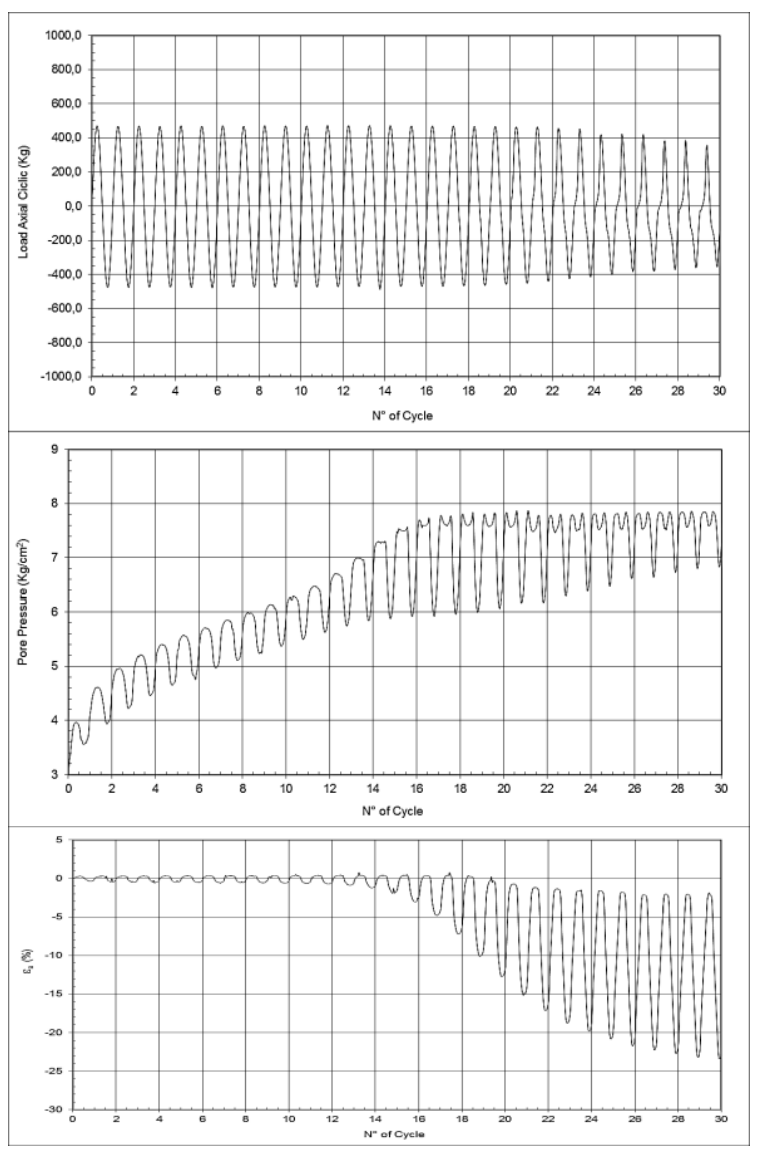

Figure 6. Cyclic triaxial test - gravel GW Ullum

Relationships ru $=\mathrm{f}(\mathrm{rn}) ; \varepsilon_{\mathrm{a}}=\mathrm{f}(\mathrm{rn})$ y $\left(\sigma_{\mathrm{dc}} / 2\right) / \sigma_{3 \mathrm{c}}{ }^{\prime}=$ $\mathrm{f}(\mathrm{Nc})$ obtained for the relative densities of interest $(\mathrm{RD}=$ $60 \%$ and $85 \%)$ and for different confining pressures $\left(\sigma 3 \mathrm{c}^{\prime}\right)$ and different cyclical deviatoric stresses $\left(\sigma_{\mathrm{dc}}\right)$, (Fig. $\left.\mathrm{N}^{\mathrm{o}} 7\right)$, allow by means of an appropiated computer program to find the pore pressure and/or the specific strain at any point of the dam or of its foundation, while the action of an earthquake.

\section{5) Conclusions}

The information obtained from both the drained triaxial tests, not drained and the constant strain status, as the cyclic triaxial tests have yielded values of shear resistance; stressstrain relationships, deformation modulus (Ei and (B); residual resistance and lines of constant strain status; consistent with the results from other known alluvial gravels in the technical literature on the subject, for example, the "Oroville Gravel" and the "gravels of the Limay River (Michihuao - Hidronor) ". We believe therefore that the results obtained are broadly satisfactory, not only in the training of human resources, but also in the theoretical-practical work, in techniques of laboratory, in the development and adaptation of the equipment, such as in the specific technical results. Due to reasons of space is not included in this job all the information that would have been desirable, occurs only with a summary of the considered the most significant or exemplary, but the rest of the same can be consulted in the Institute of Materials and Soils, Faculty of Engineering -UNSJ.
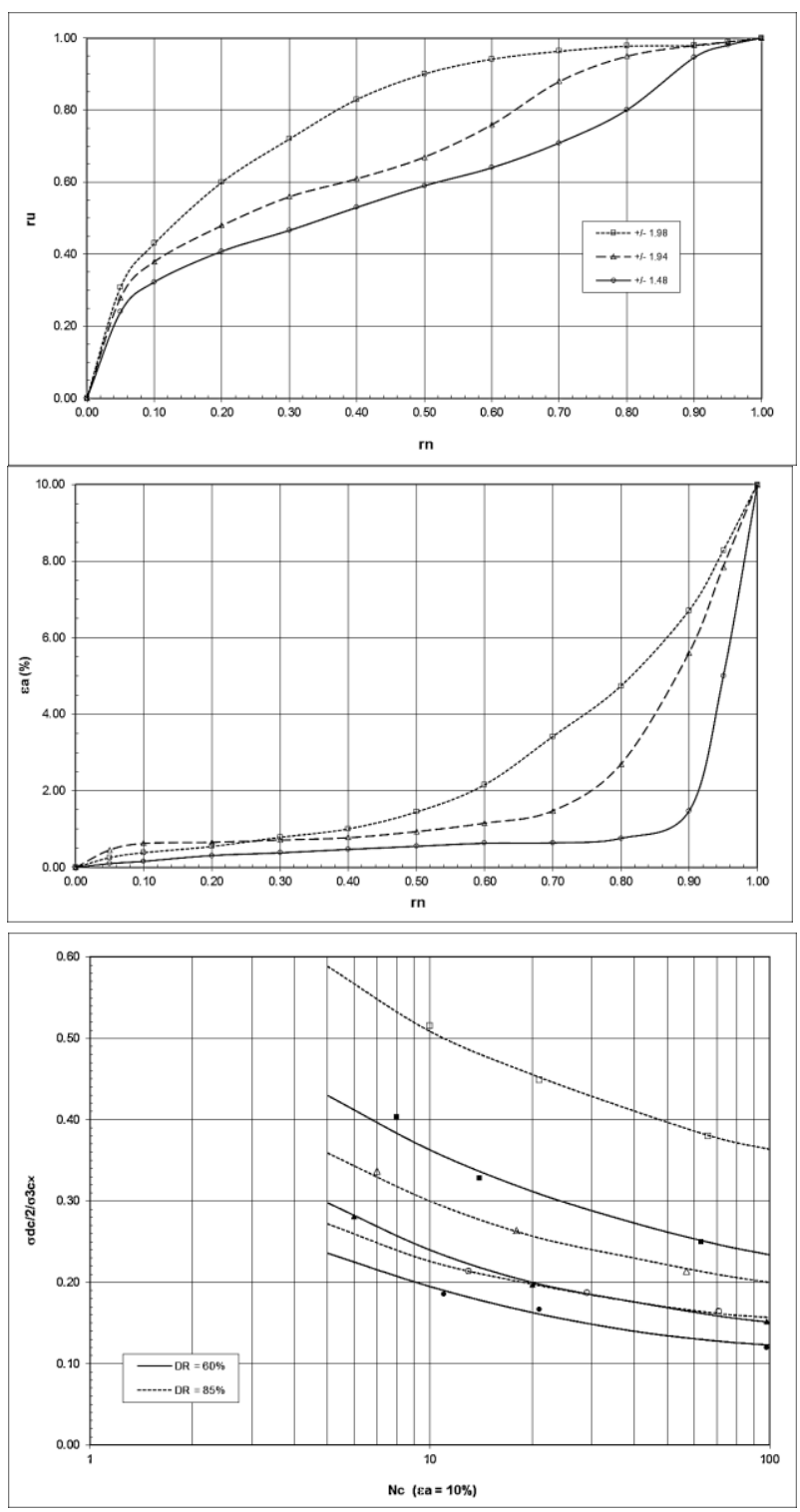

Figure 7. Parameters resistant. Cyclic triaxial test - gravel GW Ullum

\section{References}

[1] Banerjee, N. G. , SEED, H. B. , CHAN, C. K. , 1979. Cyclic Behavior of dense Coarse-Grained Materials in relation to the seismic stability of Dams - Earthquake Engineering Research Center, College of Engineering, University of California - Berkeley CA - Report NO. UBC/EERC 79/13.

[2] Bolognesi, A. J. L. , 1987 - constant state of deformation in gravels VII CPMSIF - PCSMFE - Cartagena, Colombia.

[3] Bolognesi, A. J. L. , 1988 - Granular Materials in condition not drained. - X Argentine Congress of Soil Mechanics and Foundation Engineering - I Argentine Symposium on Rock Mechanics - La Plata, Argentina.

[4] CASTRO, G. ,; Poulos, S. J. , 1977. Factors Affecting liquefaction and Cyclic Mobility - Geotechnical Engineering Division, ASCE, Vol. 103 No. GT 6.

[5] CASTRO, G. ,; Poulos, S. J. , 1982. Liquefaction Induced by cyclic loading - Geotechnical Engineering Inc. Report to National Science Foundation, U.S. Department of Commerce, National Technical Information Service / AN PB 82-235508.

[6] CHOPRA, A. K. , 1970. Earthquake Response of gravity dams - AD 709 - College of Engineering, University of California - Berkeley CA.

[7] Clough, R. W. , CHANG, K. T. , CHEN, H. Q. , STEPHEN, R. M. , 1984. Dynamic Response Behavior of Kian Hong Dian Dam - PB84 209 - College of Engineering, University of California - Berkeley CA. 
[8] EVANS, M. D. , SEED, H. B., 1987. Undrained Cyclic triaxial testing of gravel, the effect of Membrane Compliance - College of Engineering, University of California - Berkeley CA.

[9] MICUCCI, C. A. , 1988. Resistance of the gravels of Michihuao - X Argentine Congress of Soil Mechanics and Foundation Engineering I Argentine Symposium on Rock Mechanics - La Plata, Argentina.

[10] Musante, H. , Ortigosa, P. , VALENZUELA, U. , 1987. Initial Resistance to the Court in gravels - VII CPMSIF - PCSMFE Cartagena, Colombia.

[11] SEED, H. B. , Peacock, W. H. , 1970. Applicability of Laboratory Tests Procedures for measuring soil liquefaction Characteristics Under Cyclic loading - EERC 70/08 - College of Engineering, University of California - Berkeley CA.

[12] Siddiqi, F. H. , SEED R. B. , CHAN C. K., SEED, H. B. , Pyke, R. M. , 1987. Strength Evaluation of Coarse-Grained soils - Earthquake Engineering Research Center, College of Engineering, University of California - Berkeley CA - Report NO. UCB/EERC 87/22.

[13] SILVER, M. L. , SEED, H. B. , 1969. The behavior of Sands Under seismic loading conditions - EERC 69-16 - College of Engineering, University of California - Berkeley CA.

[14] KONDNER, R. L. , ZELASKO, J. S. , 1963. A hyperbolic StressStrain Formulation for Sands. Proceedings of the 2nd PanAmerican Conference on Soil Mechanics and Foundation Engineering, Vol. 1, Brazil 1963.

[15] DUNCAN, J. M. , CHANG, C. Y. , 1970. Nonlinear Analysis of stress and strain in soils.

[16] DUNCAN, J. M. , BYRNE P., WONG K. S. , MABRY P. , 1980. Stress-Strain Strength and Bulk Modulus Parameters for Finite Element Analysis of stresses and Movements in Soils Masses - Report No. UCB/GT/ 80-01, College of Engineering Office of Research Services, University of California, Berkeley, California.

[17] G. Eason, B. Noble, and I. N. Sneddon, "On certain integrals of Lipschitz-Hankel type involving products of Bessel functions," Phil. Trans. Roy. Soc. London, vol. A247, pp. 529-551, April 1955. (References)

[18] J. Clerk Maxwell, A Treatise on Electricity and magnetism, 3rd ed. vol. 2. Oxford: Clarendon, 1892, pp.68-73.

[19] I. S. Jacobs and C. P. Bean, "Fine particles, thin films and exchange anisotropy," in magnetism, vol. III, G. T. Rado and H. Suhl, EDS, New York: Academic, 1963, pp. 271-350.

[20] K. Elissa, "Title of paper if known," unpublished.

[21] R. Nicole, "Title of paper with only first word capitalized," J. Name Stand. Abbrev., in press.

[22] Y. Yorozu, M. Hirano, K. Oka, and Y. Tagawa, "electron spectroscopy studies on magneto-optical media and plastic substrate interface," IEEE Transl. J. Magn. Japan, vol. 2, pp. 740-741, August 1987 [Digests 9th Annual Conf. Magnetics Japan, p. 301, 1982].

[23] M. Young, the Technical Writer's Handbook. Mill Valley, CA: University Science, 1989.

About author (s):

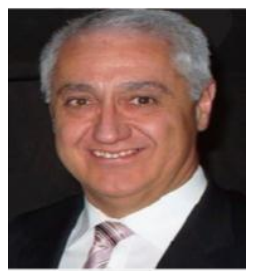

M. Cs. Ing. Civil Javier O. Morandi.

Researcher Materials and Soils Institute. San Juan National University

Argentina 